\title{
PENGARUH KOMPETENSI PETANI TERHADAP KELESTARIAN HASIL DAN USAHA HUTAN RAKYAT JATI DI KABUPATEN MUNA, SULAWESI TENGGARA
}

\section{(The Influence of Farmer Competency on Teak Farm Forestry Product and Business Sustainability in Muna District, Southeast Sulawesi)}

\author{
Musdi, Hardjanto, \& Leti Sundawati \\ Program Studi Ilmu Pengelolaan Hutan, Institut Pertanian Bogor, Jl. Lingkar Akademik, Kampus IPB, Dramaga, \\ Bogor, 16680, Indonesia; e-mail: musdi945@gmail.com, hardjanto@gmail.com, lsundawati@gmail.com
}

Diterima 15 November 2020, direvisi 2 Agustus 2021, disetujui 6 Agustus 2021

\begin{abstract}
Farm forestry is one form of farming business developed by the community in Muna District. Farm forestry businesses are expected to provide product for supporting farmer economic condition. Sustainable farm forestry management must be supported by competent farmers. Farmer's competencies consisting of knowledge, skills, attitudes, and actions have not been identified, therefore it is necessary to conduct an assessment to determine their performance in order to maintain and improve the yield and business of farm forestry. This study aims to analyze the relationship between farmer competence and the sustainability of farm forestry product and business. Data collection was taken by using purposive sampling. Data analysis uses Structural Equation Modeling (SEM) which is operated by the Linear Structural Relationship (LISREL) program. Farm forestry business is not a main livelihood for the community which makes the farmers' income does not depend on their farm forestry earnings. The results of this study indicate that the competency of farm forestry farmers and its several influencing factors have a significant impact on farm forestry sustainable management, especially in terms of product and business sustainability.
\end{abstract}

Keywords: Business; competence; farm forestry; product.

\begin{abstract}
ABSTRAK
Hutan rakyat merupakan salah satu bentuk usaha tani yang dikembangkan oleh masyarakat di Kabupaten Muna. Usaha hutan rakyat diharapkan dapat memberikan hasil yang mendukung perekonomian petani. Pengelolaan hutan rakyat yang baik harus didukung oleh petani yang kompeten. Kompetensi petani yang terdiri dari pengetahun, keterampilan, sikap, dan tindakan belum teridentifikasi sehingga perlu dilakukan penilaian untuk mengetahui kinerjanya guna menjaga dan meningkatkan hasil dan usaha hutan rakyat. Penelitian bertujuan untuk menganalisis hubungan antara kompetensi petani dengan kelestarian hasil dan usaha hutan rakyat. Pengumpulan data menggunakan purposive sampling. Analisis data menggunakan Structural Equation Modeling (SEM) yang dioperasikan dengan program Linear Structural Relationship (LISREL). Usaha hutan rakyat masih merupakan usaha sampingan sehingga pendapatan petani tidak bergantung pada hasil usaha hutan rakyat. Hasil penelitian menunjukkan bahwa kompetensi petani hutan rakyat beserta beberapa faktor yang memengaruhinya memberikan pengaruh yang nyata terhadap pengelolaan hutan rakyat yang lestari, khususnya dari segi kelestarian hasil dan usaha.
\end{abstract}

Kata kunci: Hasil; hutan rakyat; kompetensi; usaha. 


\section{PENDAHULUAN}

Pengelolaan hutan rakyat saat ini dapat dijadikan mata pencaharian yang menjanjikan bagi petani. Hal tersebut dapat dilihat dari manfaat yang dihasilkan. Dari segi sosial-ekonomi, hutan rakyat memberikan pendapatan berkelanjutan kepada petani dan dari segi ekologi sebagai penyumbang perbaikan tata air, perlindungan/pelestarian lingkungan serta solusi bagi permasalahan lingkungan (Hardjanto, Hero, \& Trisno, 2012; Widarti, 2015). Pengelolaan hutan oleh masyarakat menghadapi tantangan dalam mewujudkan pengelolaan yang berkelanjutan (Yumi, Sumardjo, Gani, \& Sugihen, 2012). Hutan rakyat dapat menjadi salah satu alternatif pemecahan masalah tekanan sumber daya hutan dengan manfaat yang dapat diperoleh dari pengelolaannya, antara lain pemenuhan kebutuhan kayu, peningkatan pendapatan masyarakat, dan peningkatan produktivitas lahan milik masyarakat (Pratama, Yuwono, \& Hilmanto, 2015), serta sebagai penghasil pangan terhadap pemenuhan kebutuhan pangan lokal (Irundu \& Fatmawati, 2019). Hutan rakyat sangat memungkinkan untuk meningkatkan pendapatan dan mengembangkan kesejahteraan petani (Saraswati \& Dharmawan, 2014) serta manfaat ekonominya dapat dirasakan secara langsung (Parlinah, Nugroho, Saleh, \& Hendrayanto, 2020).

Pengolahan hasil hutan rakyat yang hanya bertujuan untuk dipakai sendiri serta minimnya pengetahuan dan keterampilan petani dalam proses pengolahan hasil menyebabkan tidak ada tindakan pengolahan lebih lanjut untuk meningkatkan nilai tambah (Wijaya, Hardjanto, \& Hero, 2015). Pengetahuan dalam usaha hutan rakyat berasal dari orang tua, melanjutkan usaha keluarga, dan usaha turun-temurun. Keputusan teknis terkait pengelolaan hutan seperti penanaman, pemeliharaan, dan pemanenan bergantung pada keluarga yang pada umumnya dengan pertimbangan kondisi ekonomi keluarga (Hardjanto et al., 2012). Sikap dan pengetahuan memiliki peran dalam pengelolaan hutan rakyat yang dilakukan petani. Masyarakat mempunyai pengetahuan terhadap program pengembangan hutan rakyat yang didukung dengan sikap dan tindakan yang dilakukan (Waluyo, Ulya, \& Martin, 2010). Pengetahuan, keterampilan, sikap, dan tindakan dalam mengelola hutan rakyat merupakan satu kesatuan yang saling berhubungan. Kemampuan kerja setiap individu yang mencakup aspek pengetahuan, keterampilan, dan sikap kerja yang sesuai dengan standar yang ditetapkan disebut dengan kompetensi (UU No. 13, 2003; Somantrie, 2010; Cori \& Purnama, 2019).

Kecamatan Kabawo di Kabupaten Muna, Sulawesi Tenggara merupakan salah satu daerah yang petaninya mengelola hutan rakyat. Luas hutan rakyat di Kecamatan Kabawo adalah 107,06 ha (4,96\%) dari total luas hutan rakyat di Kabupaten Muna yaitu 2.159 ha. Masyarakat Kabupaten Muna memiliki minat untuk membudidayakan tanaman jati di lahan milik yang telah dimulai sejak 30 tahun lalu dan mengalami peningkatan dari tahun ke tahun. Lonjakan peningkatan jumlah tanaman hutan rakyat dan luas lahan terjadi pada periode tahun 2002-2006. Pada lima tahun sebelumnya, jumlah tanaman sebanyak 220.423 pohon dengan lahan seluas 346,69 ha. Pada 2002-2006 jumlahnya meningkat menjadi 777.791 pohon dengan luas lahan 799,06 ha. Pada periode 2007-2012, penanaman kayu di lahan milik rakyat per kecamatan tidak lebih banyak, baik luas lahan, jumlah petani, maupun luas tanaman dibandingkan pada periode sebelumnya (Dinas Kehutanan Kabupaten Muna, 2012).

Kemandirian petani dalam pengelolaan hutan rakyat masih rendah, khususnya dari segi intelektual (Ruhimat, 2014). Minimnya pengetahuan tentang manfaat yang dapat diperoleh dari pengelolaan hutan rakyat, baik manfaat ekonomi maupun terciptanya kelestarian hasil dan usaha membuat hutan 
rakyat hanya sebagai usaha sampingan. Pengetahuan masyarakat terkait pengelolaan hutan, sikap dukungan, serta tindakan masyarakat terhadap keberadaan dan pengelolaan hutan, masih kurang optimal (Garnadi, 2004; Sudrajat, Hardjanto, \& Sundawati, 2015). Kurniati \& Vaulina (2020) menyatakan bahwa kompetensi petani terhadap kinerja usaha tani berada pada kategori baik. Kompetensi petani dapat menjadi cerminan tentang bagaimana keadaan pengelolaan hutan rakyat.

Penelitian bertujuan untuk melakukan kajian tentang kompetensi petani serta hubungan antara kompetensi petani dengan kelestarian hasil dan usaha hutan rakyat jati. Hasil yang diperoleh dapat menjadi masukan untuk perbaikan pengelolaan hutan rakyat yang lestari.

\section{METODE PENELITIAN}

\section{A. Lokasi dan Waktu}

Penelitian dilaksanakan selama tiga bulan, Oktober-Desember 2017 di Kecamatan Kabawo, Kabupaten Muna, Sulawesi Tenggara. Pemilihan lokasi penelitian dilakukan secara purposive dengan mempertimbangkan luas hutan rakyat yang ada. Responden berjumlah 100 orang yang merupakan petani hutan rakyat. Penentuan jumlah sampel berdasarkan pada kebutuhan analisis data yang menggunakan Structural Equation Modelling (SEM). Sampel yang digunakan pada SEM minimal 100 sampel (Haryono, 2014).

\section{B. Kerangka Pemikiran}

Penelitian dilandasi oleh sistem pengelolaan hasil dan usaha hutan rakyat sebagai konsep utamanya, kemudian dibedah ke dalam tiga bagian. Pertama, menggali informasi tentang bagaimana kompetensi petani dalam mengelola hutan rakyat selama ini. Kompetensi dibagi menjadi empat unsur yaitu pengetahuan, keterampilan, sikap, dan tindakan. Seseorang dikatakan berkompeten apabila memiliki kemampuan, pengetahuan, keterampilan, serta motivasi dan percaya diri yang tinggi dalam mengerjakan halhal yang berkaitan dengan bidangnya. Hal tersebut dapat dilihat dari sikap dan tindakan yang dilakukan. Kedua, menganalisis hubungan antara kompetensi petani dengan kelestarian hasil dan usaha hutan rakyat. Indikator kelestarian hasil hutan rakyat terdiri atas pemenuhan aspek sosial terhadap penebangan, pengaturan hasil, dan optimalisasi pemanfaatan. Indikator kelestarian usaha hutan rakyat terdiri atas pemenuhan aspek tenaga kerja, kepemilikan lahan, dan kemampuan akses pasar.

\section{Analisis Data}

Tingkat kompetensi petani hutan rakyat diukur berdasarkan jumlah skor dari pernyataan dalam kuesioner dengan menggunakan skala Likert. Analisis kompetensi petani dalam pengelolaan hutan rakyat menggunakan analisis deskriptifkualitatif dan kuantitatif. Data yang diperoleh, diolah dan ditabulasi dengan interval yang dihasilkan pada masingmasing hasil pengukuran.

Faktor kompetensi petani (Y1) yang dianalisis mencakup kompetensi pengetahuan, keterampilan, serta sikap dan tindakan. Faktor kelestarian hasil hutan rakyat (Y2) mencakup pemenuhan aspek lingkungan dan sosial terkait penebangan, pengaturan hasil, serta efisiensi pemanfaatan hutan. Faktor kelestarian usaha hutan rakyat (Y3) mencakup pemenuhan ketenagakerjaan, kepemilikan lahan, dan kemampuan akses pasar. Cara mengetahui faktor yang memengaruhi kompetensi petani dan perannya terhadap kelestarian hasil dan usaha hutan rakyat menggunakan teknik analisis peubah ganda (multivariate analysis). Salah satu teknik analisis peubah ganda dengan menggunakan SEM yang dioperasikan melalui program Linear Structural Relationship (LISREL). LISREL merupakan program yang paling banyak 
digunakan untuk model SEM (Ramadiani, 2010).

\section{HASIL DAN PEMBAHASAN}

\section{A. Karakteristik Responden}

Responden yang dipilih merupakan petani laki-laki dan perempuan dengan kisaran umur antara 33-72 tahun. Kelompok umur terbanyak berada pada kisaran usia 41-68 tahun (68\%). Sebanyak 51\% dari total responden berpendidikan SMA dan perguruan tinggi. Sebagian besar $(60 \%)$ responden yang berpendidikan perguruan tinggi berprofesi sebagai tenaga pendidik dan tenaga medis. Jumlah tanggungan keluarga responden sebagian besar berjumlah 4-5 orang $(57 \%)$. Hal ini dapat memengaruhi jumlah pengeluaran rumah tangga dalam pemenuhan kebutuhan anggota keluarganya. Responden yang memilki pekerjaan utama sebagai petani hutan rakyat sekitar 39\%. Hal ini menjelaskan bahwa sebagian besar responden menjadikan usaha hutan rakyat sebagai pekerjaan sampingan.

Petani mengusahakan hutan rakyat jati sejak 32 tahun yang lalu, sekitar tahun 1985 . Puncaknya adalah sekitar tahun 2000-an. Petani menganggap jati merupakan tanaman yang memilki nilai jual tinggi sehingga mereka mulai mengusahakan secara serius. Luas lahan yang paling banyak diusahakan adalah $<1$ ha $(55 \%)$, beberapa di antaranya merupakan bekas lahan pertanian tidak produktif.

Ada enam motivasi utama petani dalam mengelola hutan rakyat yaitu keinginan sendiri, dukungan keluarga, manfaat dan keuntungan yang didapat, ekonomi petani terbantu, harga jual yang menguntungkan, dan mudahnya memasarkan kayu rakyat. Kepemilikan hutan rakyat tidak hanya memotivasi perencanaan dan investasi jangka panjang tetapi juga mengubah pola pikir penduduk ke arah pandangan tentang hutan yang lebih multi-fungsi dan dinamis (Devisscher, Spies, \& Griess, 2021). Usaha hutan rakyat dilakukan secara sendiri-sendiri dan berkelompok. Manfaat yang dirasakan secara berkelompok adalah sebagai sumber informasi yaitu membantu menyelesaikan masalah dan membantu dalam sistem budidaya. Minimnya informasi tentang pengelolaan hutan rakyat sangat dirasakan oleh petani. Tidak adanya peran penyuluh, baik dari pemerintah maupun tokoh masyarakat merupakan salah satu faktor penyebabnya. Sebagian besar informasi mengenai pengelolaan hutan rakyat berasal dari tetangga sesama petani walaupun ada beberapa petani yang mendapat informasi dari media masa.

\section{B. Kompetensi Petani}

Kompetensi petani dalam mengelola hutan rakyat di Kecamatan Kabawo berbedabeda, baik pengetahuan tentang hutan rakyat dan proses pengelolaannya, keterampilan, sikap yang diambil, maupun tindakan yang dilakukan. Kompetensi yang beragam secara tidak langsung dapat memengaruhi pengelolaan yang dilakukan, baik sistem produksi, proses pengolahan hasil, maupun proses pemasaran. Sistem usaha hutan rakyat terdiri atas empat sub-sistem yaitu produksi, pengolahan, pemasaran, dan kelembagaan yang keempatnya terkait secara simultan dan dinamis dalam suatu sistem (Hardjanto et al., 2012).

Peningkatan kompetensi dapat dilakukan dengan memperhatikan berbagai aspek yaitu aspek teknis, konseptual, dan relasional. Peningkatan kompetensi relasional dapat menjadi salah satu alternatif dalam pengelolaan hutan rakyat. Kompetensi relasional merupakan kemampuan untuk membangun hubungan kemitraan dalam rangka pengelolaan hutan rakyat. Sudrajat et al. (2015) menyatakan bahwa kompetensi relasional merupakan faktor yang paling berpengaruh dalam pengelolaan hutan rakyat dibandingkan dengan kompetensi lain seperti teknis dan konseptual. 


\section{Hasil Analisis SEM}

Hasil analisis SEM disajikan pada Gambar 1, Gambar 2, dan Tabel 1.

\section{Faktor yang Memengaruhi Kompetensi}

Kompetensi yang dimiliki seorang petani dalam usaha tani yang dilakukan merupakan perwujudan perilaku untuk merencanakan serangkaian aktivitas dalam mencapai target yang telah ditentukan. Kompetensi mengarah pada kemampuan petani secara menyeluruh untuk menjalankan usaha tani serta melaksanakan tugas dan fungsi pekerjaannya secara kompeten. Tabel 1 dan Gambar 2 menunjukkan hasil uji nyata terhadap 18 indikator yang digunakan. Terdapat empat indikator yang berpengaruh

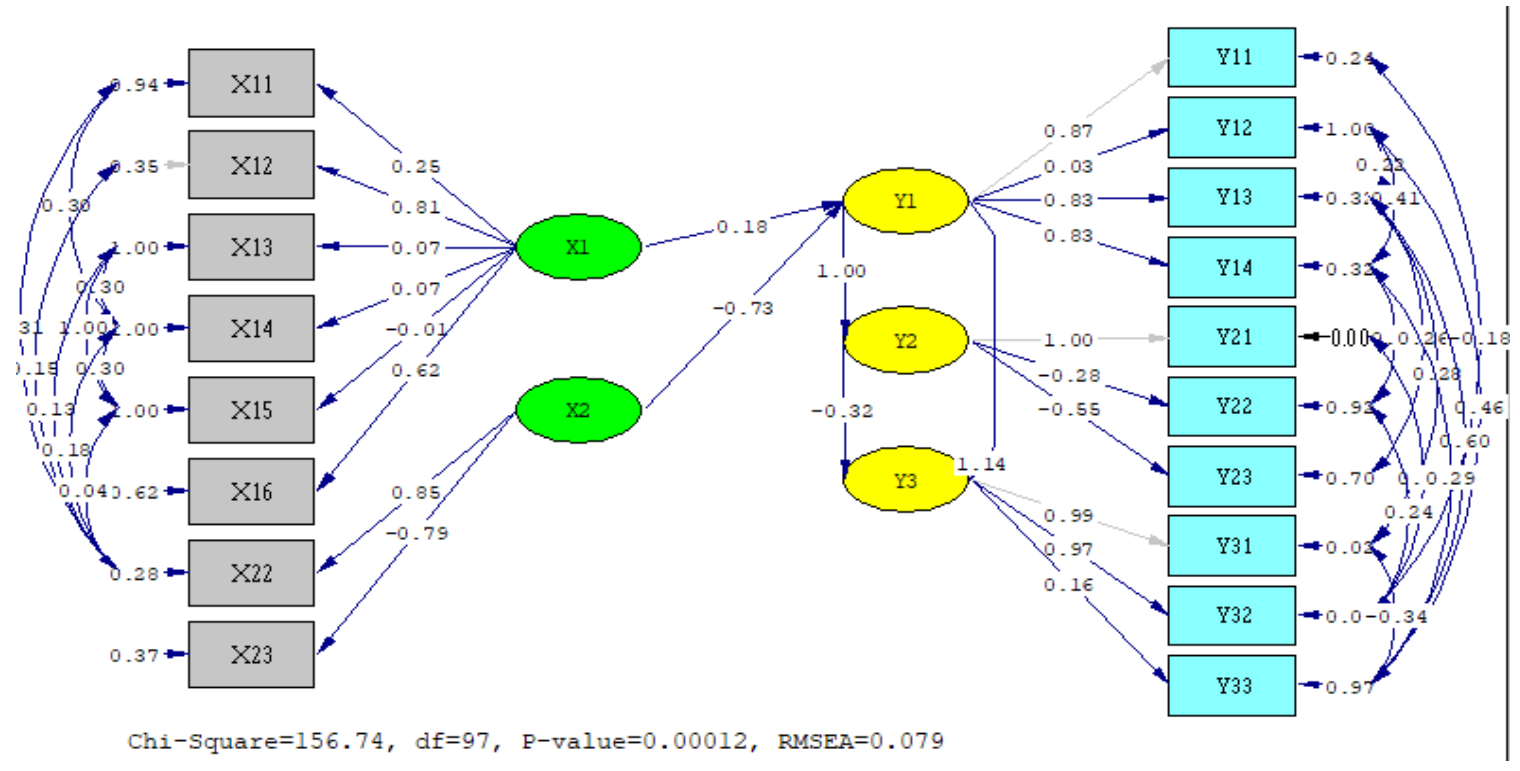

Sumber (Source): Data primer, diolah (Primary data, processed), 2018

Gambar 1 Jalur model koefisien standar dengan LISREL

Figure 1 Standardized coefficient model path with LISREL.

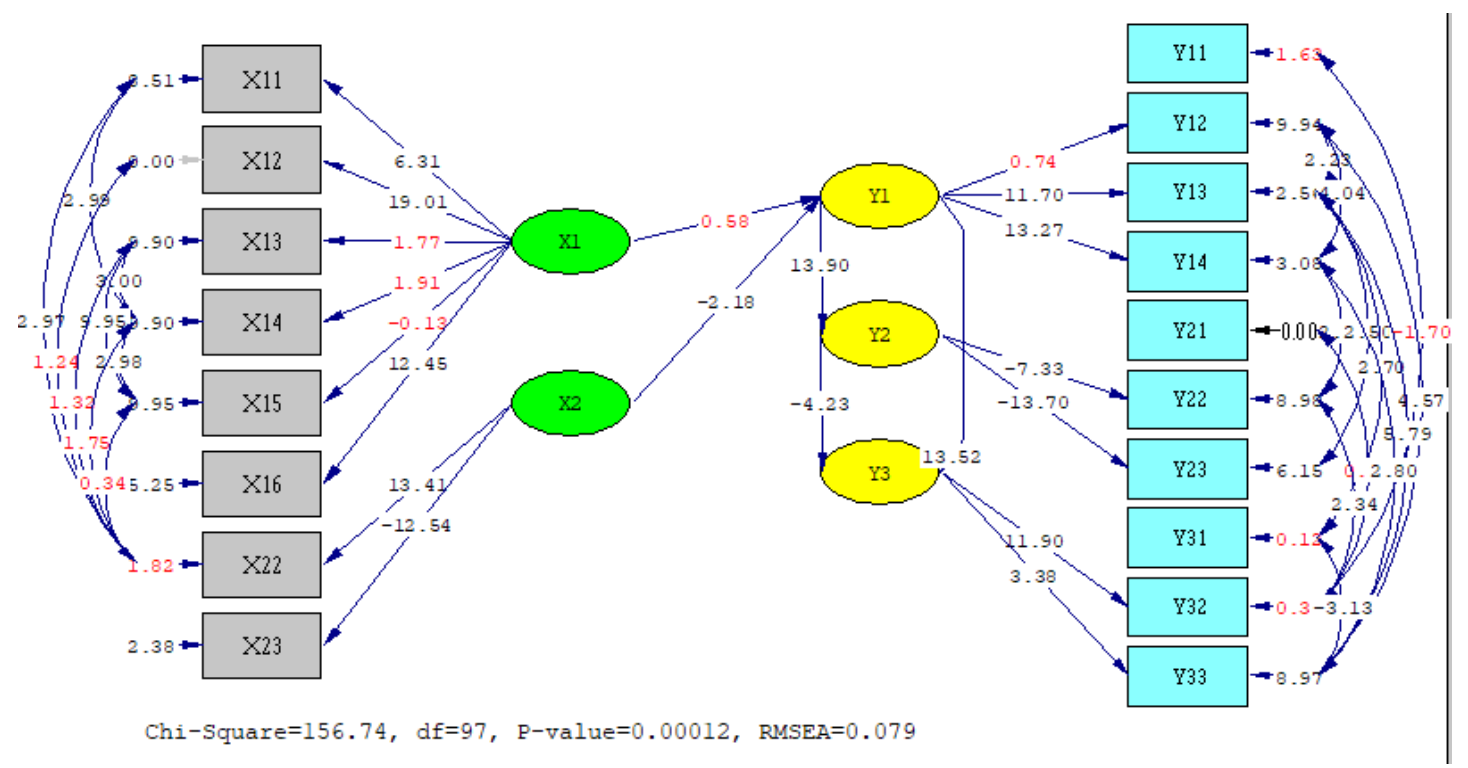

Sumber (Source): Data primer, diolah (Primary data, processed), 2018

Gambar 2 T-hitung model path dengan LISREL

Figure 2 T-calculation model path with LISREL. 
Tabel 1 Hasil uji nyata indikator

Table 1 Significant indicator test result

\begin{tabular}{|c|c|c|c|c|}
\hline $\begin{array}{l}\text { Variabel } \\
\text { (Variable) }\end{array}$ & Konstruk/indikator (Construct/indicator) & $\begin{array}{l}\text { Loading } \\
\text { factor }\end{array}$ & $\begin{array}{c}\text { t-hit } \\
(t-c a l)\end{array}$ & $\begin{array}{c}\text { Keterangan } \\
(\text { Remarks })\end{array}$ \\
\hline \multirow{6}{*}{$\begin{array}{l}\text { Internal } \\
(\text { Internal }), \mathrm{X}_{1}\end{array}$} & $\operatorname{Umur}(A g e), \mathrm{X}_{11}$ & 0,25 & 6,31 & Nyata (Significant) \\
\hline & $\begin{array}{l}\text { Tingkat pendidikan (Education level), } \\
\mathrm{X}_{12}\end{array}$ & 0,81 & 19,01 & Nyata (Significant) \\
\hline & $\begin{array}{l}\text { Pengalaman petani (Farmer experience), } \\
\mathrm{X}_{13}\end{array}$ & 0,07 & 1,77 & $\begin{array}{l}\text { Tidak nyata } \\
\text { (Not significant) }\end{array}$ \\
\hline & $\begin{array}{l}\text { Jumlah tanggungan keluarga (Number of } \\
\text { dependents), } \mathrm{X}_{14}\end{array}$ & 0,07 & 1,91 & $\begin{array}{l}\text { Tidak nyata } \\
\text { (Not significant) }\end{array}$ \\
\hline & $\begin{array}{l}\text { Luas kepemilikan HR (HR ownership } \\
\text { area), } \mathrm{X}_{15}\end{array}$ & $-0,01$ & $-0,13$ & $\begin{array}{l}\text { Tidak nyata } \\
\text { (Not significant) }\end{array}$ \\
\hline & $\begin{array}{l}\text { Motivasi berusaha (Motivation to try), } \\
\mathrm{X}_{16}\end{array}$ & 0,62 & 12,45 & Nyata (Significant) \\
\hline \multirow{2}{*}{$\begin{array}{l}\text { Eksternal } \\
(\text { External }), \mathrm{X}_{2}\end{array}$} & Kelompok tani (Farmer group), $\mathrm{X}_{22}$ & 0,85 & 13,41 & Nyata (Significant) \\
\hline & $\begin{array}{l}\text { Akses informasi (Access to information), } \\
\mathrm{X}_{23}\end{array}$ & $-0,79$ & $-12,54$ & Nyata (Significant) \\
\hline \multirow{4}{*}{$\begin{array}{l}\text { Kompetensi } \\
(\text { Competency), } \\
\mathrm{Y}_{1}\end{array}$} & Pengetahuan (Knowledge), $\mathrm{Y}_{11}$ & 0,87 & - & - \\
\hline & Keterampilan (Skills), $\mathrm{Y}_{12}$ & 0,03 & 0,74 & $\begin{array}{l}\text { Tidak nyata } \\
\text { (Not significant) }\end{array}$ \\
\hline & Sikap (Attitude), $\mathrm{Y}_{13}$ & 0,83 & 11,70 & Nyata (Significant) \\
\hline & Tindakan (Action), $\mathrm{Y}_{14}$ & 0,83 & 13,27 & Nyata (Significant) \\
\hline \multirow[t]{3}{*}{$\begin{array}{l}\text { Hasil } \\
\text { (Products), } \mathrm{Y}_{2}\end{array}$} & $\begin{array}{l}\text { Aspek sosial penebangan (The social } \\
\text { aspect of logging), } \mathrm{Y}_{21}\end{array}$ & 1,00 & - & - \\
\hline & $\begin{array}{l}\text { Pengaturan hasil (Product management), } \\
\mathrm{Y}_{22}\end{array}$ & $-0,28$ & $-7,33$ & Nyata (Significant) \\
\hline & $\begin{array}{l}\text { Efisiensi pemanfaatan (Utilization } \\
\text { efficiency), } \mathrm{Y}_{23}\end{array}$ & $-0,55$ & $-13,70$ & Nyata (Significant) \\
\hline \multirow[t]{3}{*}{$\begin{array}{l}\text { Usaha } \\
\text { (Business), } \mathrm{Y}_{3}\end{array}$} & $\begin{array}{l}\text { Aspek ketenagakerjaan (Manpower } \\
\text { aspect), } \mathrm{Y}_{31}\end{array}$ & 0,99 & - & - \\
\hline & Kepemilikan lahan (Land ownership), & 0,97 & 11,90 & Nyata (Significant) \\
\hline & $\begin{array}{l}\text { Kemampuan akses pasar (Market access } \\
\text { capability), } \mathrm{Y}_{32}\end{array}$ & 0,16 & 3,38 & Nyata (Significant) \\
\hline
\end{tabular}

Sumber (Source): Data primer, diolah (Primary data, processed), 2018.

tidak nyata, 11 indikator berpengaruh nyata dengan tiga pembanding pada taraf nyata $5 \%$ terhadap kompetensi petani.

Hasil uji hipotesis menunjukkan bahwa kompetensi petani pengelola hutan rakyat jati hanya dipengaruhi secara nyata oleh faktor eksternal sedangkan faktor internal tidak memberikan pengaruh yang nyata. Berdasarkan enam indikator penyusun faktor internal, terdapat tiga indikator yang nyata yaitu umur, tingkat pendidikan, dan motivasi berusaha. Tiga indikator yang tidak nyata yaitu pengalaman petani, jumlah tanggungan keluarga, dan kepemilikan lahan. Posisi pekerjaan petani hutan rakyat yang merupakan pekerjaan sampingan menyebabkan minimnya waktu petani dalam mengelola hutan rakyat. Indikator yang berpengaruh nyata yaitu umur, pendidikan, dan motivasi berusaha. Faktor internal yang paling besar peranannya adalah tingkat pendidikan, disusul dengan motivasi dan umur petani. Tingkat pendidikan berhubungan dengan pengetahuan, wawasan, dan keterampilan dalam pengelolaan hutan rakyat. Hal ini sejalan dengan hasil penelitian Asbi, Roslinda, \& Fahrizal (2016) yang menyatakan bahwa 
Tabel 2 Uji hipotesis faktor internal dan eksternal terhadap kompetensi

Table 2 Hypothesis of internal and external factors on competence

\begin{tabular}{|c|c|c|c|c|}
\hline $\begin{array}{c}\text { Hubungan } \\
\text { antar-variabel } \\
\text { (Correlation } \\
\text { between variables) }\end{array}$ & $\begin{array}{l}\text { Koefisien jalur } \\
\text { (Path } \\
\text { coefficient })\end{array}$ & $\begin{array}{c}\mid \text { t-hit } \mid \\
(t-c a l)\end{array}$ & $\begin{array}{l}\text { Kesimpulan } \\
\text { (Conclusion) }\end{array}$ & Keterangan (Remarks) \\
\hline $\mathrm{X}_{1}->\mathrm{Y}_{1}$ & 0,18 & 0,58 & $\begin{array}{l}\text { Tidak nyata } \\
\text { (Not significant) }\end{array}$ & \multirow{2}{*}{$\begin{array}{l}\text { Jika t hitung }>1,96 \text { maka nyata; } \\
\text { jika t hitung } \leq 1,96 \text { maka tidak } \\
\text { nyata }\end{array}$} \\
\hline $\mathrm{X}_{2}->\mathrm{Y}_{1}$ & $-0,73$ & 2,18 & Nyata (Significant) & \\
\hline
\end{tabular}

Sumber (Source): Data primer, diolah (Primary data, processed), 2018.

pengetahuan, wawasan, dan keterampilan erat kaitannya dengan tingkat pendidikan petani. Uji hipotesis faktor internal dan eksternal terhadap kompetensi dapat dilihat pada Tabel 2.

Faktor eksternal yang terdiri dari kelompok tani dan akses informasi merupakan faktor yang berpengaruh nyata terhadap kompetensi petani. Berdasarkan hasil penelitian, faktor yang paling berpengaruh adalah kelompok tani yang memberikan pengaruh besar jika dilihat dari keberadaannya di masyarakat. Supriono, Bowo, Kosasih, \& Herawati, (2013); Mawarni, Baruwadi, \& Bempah (2017) menyatakan bahwa kondisi kelompok tani hutan rakyat memiliki posisi yang kuat. Keterlibatan anggota kelompok tani dalam aktivitas budidaya di lokasi penelitian menumbuhkan kesadaran anggota kelompok lain untuk memanfaatkan lahan yang dimiliki untuk menanam tanaman jati. Muttaqin (2014) menyatakan bahwa aktivitas anggota kelompok dapat menumbuhkan kesadaran anggota tani lain dalam pemanfaatan lahan yang dimiliki.

Kerja sama dalam kelompok tani sangat membantu pengelolaan hutan rakyat. Kerja sama tersebut dapat berupa saling membantu dan bertukar informasi terkait pengetahuan tentang pengelolaan hutan rakyat. Dengan demikian maka ketidakmerataan keterampilan petani dalam pengusahaan hutan rakyat dapat teratasi. Petani dapat menentukan bagaimana cara bersikap dan bertindak dalam pengelolaan hutan rakyat.
Selain kelompok tani, akses informasi juga berperan penting terhadap tinggirendahnya kompetensi petani. Banyaknya informasi yang didapat serta seringnya petani mengakses informasi akan memberikan nilai tambah terhadap pengetahuan petani.

\section{E. Kelestarian Hasil dan Usaha Hutan Rakyat}

\section{Kelestarian Hasil}

Hasil utama pemanfaatan kayu rakyat diperoleh dari nilai ekonomi penjualan kayu. Selain untuk dijual, kayu rakyat juga dimanfaatkan untuk konsumsi guna memenuhi kebutuhan sendiri seperti untuk kayu bakar dan konstruksi rumah. Sisa pemanenan seperti dahan dan ranting dijadikan kayu bakar dan pagar. Untuk pohon, masyarakat hanya memanfaatkan bagian kayunya sedangkan daun dan akar jati belum dimanfaatkan untuk menambah nilai ekonomi. Sebagian besar pola tanam yang diterapkan adalah monokultur (81\%). Petani beranggapan bahwa pola tanam monokultur merupakan bentuk pola tanam yang mudah dalam proses pengelolaannya. Perlakuan yang dilakukan cenderung sama, perawatan yang tidak terlalu sulit, hingga curahan waktu di lapangan yang lebih sedikit. Tingkat interaksi dengan hutan mempunyai hubungan yang nyata dengan sikap masyarakat sekitar hutan (Surati, 2014).

Pemanenan dilakukan petani ketika tanaman jati berumur 20 tahun atau lebih. Petani menganggap umur tersebut 
merupakan umur masak tebang sehingga ideal untuk pemanenan. Sistem tebang butuh dilakukan pada saat petani membutuhkan dana cepat yang tidak dapat ditunda, misalnya melanjutkan pendidikan, acara pernikahan, membeli kendaraan, atau modal usaha. Pemilihan pohon yang ditebang didasarkan pada ukuran diameter $>50 \mathrm{~cm}$ walaupun belum masak tebang atau pohon yang terserang hama dan penyakit (Sanudin \& Priambodo, 2013).

Keputusan penebangan selalu melibatkan anggota keluarga, baik mengenai jumlah maupun waktu penebangan. Hal ini karena dalam proses penebangan, anggota keluarga selalu terlibat, baik secara langsung maupun tidak langsung. Keterlibatan secara langsung seperti ikut dalam proses penebangan sedangkan secara tidak langsung adalah menyiapkan makan siang untuk penebang. Kelompok tani tidak dilibatkan secara langsung dalam proses penebangan namun petani lain turut membantu.

Petani lebih memilih tidak melakukan pengurusan pengizinan, dalam hal ini berkaitan dengan Surat Keterangan Asal Usul (SKAU). Selain karena skala penebangan masih tergolong kecil, petani beranggapan bahwa pohon yang ditanam merupakan milik pribadi sehingga tidak butuh perizinan untuk menebang. Asal-usul hasil hutan dapat menimbulkan masalah bagi pemilik hasil hutan rakyat ketika terjadi pemeriksaan persyaratan administrasi. Peraturan Menteri Lingkungan Hidup dan Kehutanan (Permen LHK) No. P21 tahun 2015 tentang Penatausahaan Hasil Hutan yang Berasal dari Hutan Hak menyebutkan bahwa surat keterangan asal usul hasil hutan yang berasal dari hutan hak berupa Nota Angkutan dan SKAU perlu dipenuhi. Peraturan ini menjelaskan bahwa SKAU dapat membuktikan kepemilikan kayu yang sah dan menghindarkan petani dari masalah yang akan dihadapi ketika terjadi pemeriksaan oleh petugas yang berwenang.

\section{Kelestarian Usaha}

Luasan lahan petani pengelola hutan rakyat di lokasi penelitian didominasi luasan $<1$ ha. Dominasi tersebut merupakan 55\% dari total luas keseluruhan 83,63 ha. Luasan lahan yang terbatas dapat dioptimalkan dengan cara memperluas kegiatan masyarakat serta mengembangkan jaringan informasi dan komunikasi (Rizal, Nurhaedah, \& Hapsari, 2012). Status pemilikan lahan adalah lahan pribadi yang dikelola masingmasing keluarga. Petani yang memiliki sertifikat tanah mencapai $78 \%$ dari total 100 responden. Petani masih beranggapan bahwa tanpa sertifikat tanah pun mereka bisa tetap mengelola lahan yang dikuasainya. Ada juga yang beranggapan bahwa pengurusan sertifikat tanah membutuhkan waktu yang cukup lama. Selama ini, tidak pernah terjadi permasalahan status kepemilikan lahan. Batas fisik masing-masing lahan berupa pagar dari batang pohon serta sisa pembukaan/pembersihan lahan. Berdasarkan hasil penelitian, sebagian besar responden merupakan petani lahan sempit $(<1 \mathrm{ha})$ dengan pola tanam dominan monokultur. Hal tersebut perlu mendapatkan perhatian. Besarnya pendapatan dari usaha hutan rakyat dipengaruhi oleh luas lahan (Achmad, Purwanto, Sabarnurdin, \& Sumardi 2015). Selain itu, untuk mewujudkan pengelolaan yang lestari maka diperlukan pelatihan dan pendampingan terhadap petani hutan rakyat lahan sempit dengan pola tanam monokultur (Palmolina, 2015).

Sebagian besar tenaga kerja yang digunakan pada pengelolaan hutan rakyat adalah anggota keluarga yang terdiri atas anak, suami/istri, saudara, dan orang tua. Rekan-rekan sesama petani juga terlibat, bahkan tetangga yang tidak memiliki hutan rakyat pun biasa membantu. Mereka biasanya dilibatkan dalam proses pembukaan lahan, mulai dari pembersihan lahan hingga penanaman. Mereka tidak mengenal sistem upah karena mereka bekerja atas rasa 
kekeluargaan dan saling membantu. Mereka hanya berpikir bahwa sewaktu-waktu akan membutuhkan tenaga orang lain. Walaupun demikian, tenaga upahan kadangkala digunakan pada saat pemanenan. Cara ini dipilih karena keterbatasan jumlah tenaga terdidik yang memahami proses pemanenan. Tenaga upahan dianggap memiliki pengetahuan dan pengalaman yang lebih sehingga dapat meningkatkan pendapatan dari proses pemanenan. Besarnya pendapatan dari usaha hutan rakyat dipengaruhi oleh berapa banyak jumlah tenaga kerja terdidik (Achmad et al., 2015).

Petani di lokasi penelitian menganggap bahwa hasil hutan rakyat berupa kayu jati masih cukup mudah dipasarkan. Ketersediaan informasi tentang harga umum kayu rakyat sangat membantu petani, mulai dari spesifikasi jenis, kualitas, serta ukuran kayu yang dibutuhkan. Petani masih memasarkan hasil kayu rakyatnya dalam skala lokal. Mereka biasanya menjual kepada pengumpul dan masyarakat lokal. Pengumpul biasanya membeli kayu rakyat untuk dijual kembali dalam bentuk kayu olahan sedangkan masyarakat membeli untuk pembuatan kerangka rumah dan beberapa keperluan lain. Ketersediaan industri pengolahan merupakan salah satu faktor pendukung dalam pengelolaan hasil hutan rakyat. Luas lahan, potensi, praktik silvikultur, kelembagaan kelompok tani, dan ketersediaan pasar/keberadaan industri berpengaruh nyata dalam pengembangan agribisnis hutan rakyat namun yang paling berpengaruh adalah faktor ketersediaan pasar/keberadaan industri pengolah hasil hutan (Basriwijaya \& Maryoni, 2017).

\section{Hubungan Kompetensi dengan Kelestaian Hasil dan Usaha Hutan Rakyat}

Untuk menciptakan petani-petani yang memiliki kompetensi yang baik dalam pengelolaan hutan rakyat, perlu dilakukan kajian guna mengetahui sampai di mana kompetensi petani saat ini. Hal tersebut menjadi salah satu informasi yang dapat dipakai dalam pengelolaan hutan rakyat untuk menciptakan pengelolaan hutan rakyat yang berkelanjutan. Hasil uji hipotesis kompetensi petani di Kecamatan Kabawo terhadap kelestarian hasil usaha hutan rakyat disajikan pada Tabel 3 .

Tabel 3 menunjukkan bahwa kompetensi petani memberikan pengaruh yang nyata terhadap kelestarian hasil dan usaha hutan rakyat jati. Selain itu, kelestarian hasil hutan rakyat memberikan pengaruh yang nyata terhadap usaha hutan rakyat yang dilakukan oleh petani di Kecamatan Kabawo. Kelestarian hasil dan usaha merupakan keberlanjutan dan/atau peningkatan produksi hasil kayu dari waktu ke waktu karena kemampuan pemilik atau kerja sama antara pemilik pengelola hutan rakyat (Hardjanto, 2017).

Mencermati hasil analisis SEM, kompetensi petani hutan rakyat beserta beberapa faktor yang memengaruhinya memberikan pengaruh yang nyata terhadap pengelolaan hutan rakyat yang lestari, khususnya dari segi kelestarian usaha.

Tabel 3 Uji hipotesis kompetensi terhadap kelestarian hasil dan usaha

Table 3 Competency hypothesis test on product and business sustainability

\begin{tabular}{ccccl}
\hline $\begin{array}{c}\text { Hubungan antar- } \\
\text { variabel (Correlation } \\
\text { between variables) }\end{array}$ & $\begin{array}{c}\text { Koefisien } \\
\text { jalur }(\text { Path } \\
\text { coefficient) }\end{array}$ & $\begin{array}{c}\mid \mathrm{t} \text {-hit } \mid \\
(t \text {-cal })\end{array}$ & $\begin{array}{c}\text { Kesimpulan } \\
(\text { Conclusion })\end{array}$ & Keterangan (Remarks) \\
\hline $\mathrm{Y}_{1}->\mathrm{Y}_{2}$ & 1,00 & 13,90 & Nyata (Significant) & Jika t hitung $>1,96$ maka nyata; \\
$\mathrm{Y}_{1}->\mathrm{Y}_{3}$ & 1,14 & 13,52 & Nyata (Significant) & jika t hitung $\leq 1,96$ maka tidak \\
$\mathrm{Y}_{2}->\mathrm{Y}_{3}$ & -032 & 4,23 & Nyata (Significant) & nyata \\
\hline
\end{tabular}

Sumber (Source): Data primer, diolah (Primary data, processed), 2018. 
Kompetensi yang berpengaruh nyata adalah pengetahuan, sikap, dan tindakan. Pengetahuan petani terhadap apa itu hutan rakyat sudah dipahami dengan baik. Sikap petani yang dominan setuju untuk menjaga keseimbangan produksi, pemilihan jenis tanaman jati sebagai tanaman yang diusahakan di hutan rakyat, serta usaha hutan rakyat sebagai salah satu alternatif dalam memenuhi kebutuhan ekonomi petani. Tindakan yang dilakukan dalam budidaya, rata-rata petani memulai usaha hutan rakyatnya dari persiapan lahan, penanaman, pemeliharaan, dan pemanenan. Kompetensi petani terkait pengetahuan, keterampilan, sikap, dan tindakan petani tentang pengelolaan hutan rakyat jati berasal dari orang tua dan tetangga yang merupakan seorang petani. Hardjanto et al. (2012) menyatakan bahwa pengetahuan petani pengelola hutan rakyat berasal dari orang tua, melanjutkan usaha keluarga, dan usaha turun-temurun. Pengetahuan yang terbatas serta keterampilan yang diperoleh dari pengalaman bertani selama ini sudah cukup untuk membimbing petani bagaimana cara petani bersikap dan bertindak dalam pengelolaan hutan rakyat jati menuju pengelolaan yang lestari. Sikap petani untuk menjaga kelestarian hutan dalam bertani dibentuk dari pengetahuan mereka (Masalamate, Benu, \& Pakasi, 2015). Selain itu, keterkaitan emosional dengan hutan memengaruhi sikap pemiliki untuk melindungi keberadaan hutan rakyat (Miljand, Bjarstig, Eckerberg, \& Primer, 2021).

Pengelolaan hutan rakyat berdasarkan pada pengetahuan lokal yang dimiliki masyarakat (Sudomo \& Hani, 2014). Pengetahuan yang terbatas tidak membatasi petani maupun menurunkan niat dan semangat dalam pengelolaan. Usaha hutan rakyat yang masih merupakan sampingan disebabkan karena pekerjaan utama sebagian besar responden bukan sebagai petani hutan rakyat sehingga pendapatan tidak bergantung pada hasil dan usaha hutan rakyat. Anggapan tersebut dapat diubah sehingga usaha hutan rakyat menjadi mata pencaharian utama yang dapat mencukupi kebutuhan perekonomian petani.

Pengelolaan hutan rakyat dalam skala besar dapat membuka lapangan kerja baru bagi masyarakat pedesaan. Hal tersebut didasarkan pada perekrutan tenaga kerja sehingga mengurangi jumlah pengangguran. Hutan rakyat dapat menggerakkan roda perekonomian masyarakat yang ikut berperan di dalam pengelolaannya. Mengusahakan hutan rakyat, secara tidak langsung dapat membantu pemerintah serta ikut berperan dalam penyediaan dan pemenuhan kebutuhan kayu dalam negeri.

\section{KESIMPULAN DAN SARAN}

\section{A. Kesimpulan}

Usaha hutan rakyat masih merupakan pekerjaan sampingan sehingga pendapatan petani tidak bergantung dari hasil usaha hutan rakyat. Kompetensi petani hutan rakyat beserta beberapa faktor yang memengaruhinya memberikan pengaruh yang nyata terhadap pengelolaan hutan rakyat lestari, khususnya dari segi kelestarian hasil dan usaha. Indikator kompetensi yang berpengaruh nyata adalah pengetahuan, sikap, dan tindakan petani.

\section{B. Saran}

Terkait tingkat kompetensi petani hutan rakyat di Kecamatan Kabawo, pendampingan secara intensif oleh penyuluh merupakan solusi yang sangat dibutuhkan oleh petani dalam mengelola hutan rakyat. Pendampingan dapat dilakukan dengan memberikan pemahaman dan pelatihan bagaimana proses pengelolaan hutan rakyat sejak penanaman, pemeliharaan, pemanenan, hingga proses pemasaran. Penyuluh diharapkan dapat memberikan informasi guna menambah pengetahuan dan keterampilan serta dapat mengarahkan sikap serta cara bertindak. Kesadaran untuk 
melengkapi SKAU atas pengangkutan kayu merupakan faktor yang harus diperhatikan dalam proses pemanenan.

\section{UCAPAN TERIMA KASIH (ACKNOWLEDGEMENT)}

Penulis mengucapkan terima kasih kepada Allah SWT, kedua dosen pembimbing Prof. Dr. Ir. Hardjanto, MS. dan Dr. Ir. Leti Sundawati, M.Sc. FTrop, kedua orang tua dan keluarga, Camat Kecamatan Kabawo, serta rekan-rekan yang telah membantu selama penulis menyelesaikan tulisan ini.

\section{DAFTAR PUSTAKA}

Achmad, B., Purwanto, R. H., Sabarnurdin, S., \& Sumardi. (2015). Tingkat pendapatan dan curahan tenaga kerja pada hutan rakyat di Kabupaten Ciamis. Jurnal Ilmu Kehutanan, 9(2), 105-116.

Asbi, Roslinda, E. \& Fahrizal. (2016). Persepsi kelompok tani hutan rakyat terhadap jenis gaharu di Desa Nusapati, Kecamatan Sungai Pinyuh, Kabupaten Mempawai. Jurnal Hutan Lestari, 4(4), 685-692.

Basriwijaya, K.M.Z. \& Maryoni. (2017). Potensi pengembangan agribisnis: studi kasus hutan rakyat Kecamatan Kandangan, Kabupaten Temanggung. Jurnal Sungkai, 5(2), 16-29.

Cori, C. \& Purnama, L. (2019). Pengaruh faktor sumberdaya manusia terhadap kinerja. Jurnal Transaksi, 11(1), 22-30.

Dinas Kehutanan Kabupaten Muna. (2012). Hutan rakyat. Muna: Dinas Kehutanan Kabupaten Muna.

Devisscher, T., Spies, J., \& Griess, V.C. (2021). Time for change: learning from community forests to enhance the resilience of multi-value forestry in British Columbia Canada. Land Use Policy, 103.

Garnadi, D. (2004). Pengetahuan sikap dan tindakan masyarakat sekitar hutan terhadap hutan. (Tesis). Institut Pertanian Bogor, Bogor.

Hardjanto, Hero, Y., \& Trisno, S. (2012). Desain kelembagaan usaha hutan rakyat untuk mewujudkan kelestarian hutan dan kelestarian usaha dalam upaya pengentasan kemiskinan masyarakat pedesaan. Jurnal Ilmu Pertanian Indonesia, 17(2), 103-107.

Hardjanto. (2017). Pengelolaan hutan rakyat. Bogor: IPB Pres.
Haryono, S. (2014). Mengenal metode structural equation modeling (SEM) untuk penelitian manajemen menggunakan AMOS. Jurnal Ekonomi dan Bisnis STIE YPN, 7(1), 23-34.

Irundu, D. \& Fatmawati, D. (2019). Potensi hutan rakyat sebagai penghasil pangan di Desa Paku, Kabupaten Polman, Sulawesi Barat. Jurnal Hutan dan Masyarakat, 11(1), 41-48.

Kurniati, S. \& Vaulina, S. (2020). Pengaruh karakteristik petani dan kompetensi terhadap kinerja petani pada padi sawah di Kecamatan Gunung Toar, Kabupaten Kuantan Singingi. Jurnal Agribisnis, 22(1), 82-94.

Masalamate, P. M., Benu, O. L. S., \& Pakasi, C. B. D. (2015). Perilaku petani di sekitar Hutan Lindung Soputan dan Manimporok, Kecamatan Ratahan, Kabupaten Minahasa Tenggara. COCOS, 6(14).

Mawarni, E., Baruwadi, M., \& Bempah, I. (2017). Peran kelompok tani dalam peningkatan pendapatan petani padi sawah di Desa Iloheluma, Kecamatan Tilongkabila, Kabupaten Bone Bolango. Agrinesia, 2(1), 65-73.

Miljand, M., Bjarstig, T., Eckerberg, K., \& Primmer, E. (2021). Voluntary agreements to protect private forest a realist review. Forest Policy and Economics, 128, 1-14.

Muttaqin, T. (2014). Pendampingan kelompok tani hutan rakyat Desa Donowarih, Kecamatan Karangploso, Kabupaten Malang dalam peningkatan usaha budidaya tanaman sengon. Dedikasi, 11, 95-101.

Palmolina, M. (2015). Pengelolaan hutan rakyat pada lahan sempit. Prosiding Seminar Nasional Masyarakat Biodiversitas Indonesia, 1(4), 732737.

Parlinah, N., Nugroho, B., Saleh, M. B., \& Hendrayanto. (2020). Implikasi hak kepemilikan dan konversi hutan rakyat: studi kasus daerah tangkapan air Waduk Jatigede. Jurnal Penelitian Sosisal dan Ekonomi Kehutanan, 17(2), 137151.

Peraturan Menteri Lingkungan Hidup dan Kehutanan No. 21 tahun 2015 tentang Penatausahaan Hasil Hutan yang Berasal dari Hutan Hak.

Pratama, A. R., Yuwono, S. B., \& Hilmanto, R. (2015). Pengelolaan hutan rakyat oleh kelompok pemilik hutan rakyat di Desa Bandar Dalam, Kecamatan Sidomulyo, Kabupaten Lampung Selatan. Jurnal Sylva Lestari, 3(2), 99-112.

Ramadiani. (2010). SEM dan LISREL untuk analisis multivariate. Jurnal Sistem Informasi, 179-188.

Rizal, A. H. B., Nurhaedah, \& Hapsari, E. (2012). Kajian strategi optimalisasi pemanfaatan lahan hutan rakyat di Provinsi Sulawesi Selatan. Jurnal Penelitian Sosial dan Ekonomi Kehutanan, 9(4), 216-228. 
Ruhimat, I. S. (2014). Faktor-faktor untuk peningkatan kemandirian petani dalam pengelolaan hutan rakyat: studi kasus di Desa Ranggang, Kabupaten Tanah Laut, Kalimantan Selatan. Jurnal Penelitian Sosial dan Ekonomi Kehutanan, 11(3), $237-249$.

Sanudin \& Priambodo, D. (2013). Analisis sistem dalam pengelolaan hutan rakyat agroforestry di hulu DAS Citanduy: kasus di Desa Sukamaju, Ciamis. Jurnal Online Pertanian Tropika Pasca Sarjana FP USU, 1(1), 33-46.

Saraswati, Y. \& Dharmawan, A. H. (2014). Resiliensi nafkah rumah tangga petani hutan rakyat di Kecamatan Giriwoyo, Wonogiri. Jurnal Sosiologi Pedesaan, 8(1), 71-84.

Somantrie, H. (2010). Kompetensi sebagai landasan konseptual kebijakan kurikulum sekolah di Indonesia. Jurnal Pendidikan dan Kebudayaan, 16(6), 684-698.

Sudomo, A. \& Hani, A. (2014). Produktivitas talas di bawah tiga jenis tegakan dengan sistem agroforestry di lahan hutan rakyat. Jurnal Ilmu Kehutanan, 8(2), 100-107.

Sudrajat, A., Hardjanto, \& Sundawati, L. (2015). Partisispasi petani dalam pengelolaan hutan rakyat lestari: kasus di Desa Cikeusal dan Desa Kananga, Kabupaten Kuningan. Jurnal Silvikultur Tropika, 7(1), 8-17.
Supriono, A., Bowo, C., Kosasih, A. S., \& Herawati, T. (2013). Strategi penguatan kapasitas kelompok tani hutan rakyat di Kabupaten Situbondo. Jurnal Penelitian Hutan Tanaman, 10(3), 139-146.

Surati. (2014). Analisis sikap dan perilaku masyarakat terhadap Hutan Penelitian Parung Panjang. Jurnal Penelitian Sosial dan Ekonomi Kehutanan, 11(4), 339-347.

Undang-Undang No. 13 tahun 2003 tentang Ketenagakerjaan.

Waluyo, E. A., Ulya, N. A., \& Martin, E. (2010). Perencanaan sosial dalam rangka pengembangan hutan rakyat di Sumatera Selatan. Jurnal Penelitian dan Konservasi Alam, 7(3), 271-280.

Widarti, A. (2015). Kontribusi hutan rakyat untuk kelestarian lingkungan dan pendapatan. Prosiding Seminar Nasional Masyarakat Biodiversitas Indonesia, 1(7), 1622-1626.

Wijaya, A., Hardjanto, \& Hero, Y. (2015). Analisis finansial dan pendapatan hutan rakyat pulai (Alstonia sp.) di Kabupaten Musi Rawas, Propinsi Sumatera Selatan. Jurnal Silvikultur Tropika, 6(3), 148-159.

Yumi, Sumardjo, Gani, D. S., \& Sugihen, B. G. (2012). Kelembagaan pendukung pembelajaran petani dalam pengelolaan hutan rakyat lestari. Jurnal Penyuluhan, 8(1), 15-28. 